Louisiana State University

LSU Digital Commons

Faculty Publications

Department of Biological Sciences

$1-1-2003$

\title{
Influence of the El Niño Southern Oscillation on fire regimes in the Florida Everglades
}

\author{
Brian Beckage \\ Louisiana State University \\ William J. Platt \\ Louisiana State University \\ Matthew G. Slocum \\ Louisiana State University \\ Bob Panko \\ Everglades National Park
}

Follow this and additional works at: https://digitalcommons.Isu.edu/biosci_pubs

\section{Recommended Citation}

Beckage, B., Platt, W., Slocum, M., \& Panko, B. (2003). Influence of the El Niño Southern Oscillation on fire regimes in the Florida Everglades. Ecology, 84 (12), 3124-3130. https://doi.org/10.1890/02-0183

This Article is brought to you for free and open access by the Department of Biological Sciences at LSU Digital Commons. It has been accepted for inclusion in Faculty Publications by an authorized administrator of LSU Digital Commons. For more information, please contact ir@lsu.edu. 


\title{
INFLUENCE OF THE EL NIÑO SOUTHERN OSCILLATION ON FIRE REGIMES IN THE FLORIDA EVERGLADES
}

\author{
Brian Beckage, ${ }^{1,3}$ William J. Platt, ${ }^{1}$ Matthew G. Slocum, ${ }^{1,4}$ and Bob Panko ${ }^{2}$ \\ ${ }^{1}$ Department of Biological Sciences, Louisiana State University, Baton Rouge, Louisiana 70803 USA \\ ${ }^{2}$ Everglades National Park, 40001 State Route 9336, Homestead, Florida 33034 USA
}

\begin{abstract}
Disturbances that are strongly linked to global climatic cycles may occur in a regular, predictable manner that affects composition and distribution of ecological communities. The El Niño Southern Oscillation (ENSO) influences worldwide precipitation patterns and has occurred with regular periodicity over the last 130000 years. We hypothesized that ENSO, through effects on local weather conditions, has influenced frequency and extent of fires within Everglades National Park (Florida, USA). Using data from 1948 to 1999 , we found that the La Niña phase of ENSO was associated with decreased dryseason rainfall, lowered surface water levels, increased lightning strikes, more fires, and larger areas burned. In contrast, the El Niño phase was associated with increased dry-season rainfall, raised surface water levels, decreased lightning strikes, fewer fires, and smaller areas burned. Shifts between ENSO phases every few years have likely influenced vegetation through periodic large-scale fires, resulting in a prevalence of fire-influenced communities in the Everglades landscape.
\end{abstract}

Key words: area burned; El Niño; ENSO; Everglades; fire; Florida; global warming; La Niña; lightning; savannas; SOI; wet/dry season.

\section{INTRODUCTION}

Fire is a pervasive natural disturbance in many landscapes (Bond and van Wilgen 1996). Fires depress some plant populations, but enhance others (e.g., Glitzenstein et al. 1995, Beckage and Stout 2000), influencing the composition and extent of communities (e.g., Johnson 1992, Higgins et al. 2000). A fire regime that is predictable (i.e., with regular periods of increased fire likelihood) can increase the potential for evolutionary responses to fire and strengthen effects on plant populations and communities as subsequent disturbances reinforce effects of prior ones (Mutch 1970, Platt 1999, Bond and Midgeley 2001).

Predictable fire regimes may result from global climatic cycles that produce conditions favoring largescale fires (Johnson 1992, Veblen and Kitzberger 2002). One such climatic cycle is the El Niño Southern Oscillation (ENSO). ENSO cycles, characterized by alternating periods of warm (El Niño phase) or cold (La Niña phase) sea surface temperatures in the central and eastern Pacific, have occurred with a periodicity between three and seven years for the last 130000 years (Tudhope et al. 2001). ENSO events affect global rainfall patterns (Allan et al. 1996) and have been asso-

Manuscript received 2 April 2002; revised 3 April 2003; accepted 22 April 2003; final version received 9 June 2003. Corresponding Editor: K. D. Woods.

${ }^{3}$ Present address: Botany Department, Marsh Life Science Building, University of Vermont, Burlington, Vermont 05405. E-mail: bbeckage@uvm.edu

${ }^{4}$ Present address: Wetland Biogeochemistry and Coastal Institute, Louisiana State University, Baton Rouge, Louisiana 70803 USA. ciated with increased occurrence of fires at subcontinental scales (Swetnam and Betancourt 1990, Brenner 1991, Veblen and Kitzberger 2002). The precise mechanisms underlying ENSO-fire relationships may not be apparent at subcontinental scales because many different landscapes occur in such broad regions but may be evident at local, landscape scales.

We explored relationships between ENSO cycles, local weather patterns, and fires within Everglades National Park (USA) to address two questions: Are frequency and extent of fires within the Park related to ENSO cycles? Can we propose mechanisms whereby ENSO cycles influence local fire regimes? We addressed these questions using time series data for global ENSO cycles, long-term records for rainfall, surface water levels, and number of lightning strikes in the Everglades region, and a 52-year record of fires in Everglades National Park.

\section{Methods \\ Study area}

Everglades National Park is $3600 \mathrm{~km}^{2}$ (exclusive of marine areas), primarily $<2 \mathrm{~m}$ above sea level with little relief (slope $<3 \mathrm{~cm} / \mathrm{km}$ ). The major source of water is rainfall draining through a broad, slowly moving "river of grass" extending from Lake Okeechobee southwest to the Gulf of Mexico (Douglas 1947). Ecological communities are zoned by elevation relative to this central drainage. Salt/brackish marshes and mangroves $\left(1920 \mathrm{~km}^{2}\right.$ in area) occur along the coast at elevations $<0.5 \mathrm{~m}$. Short- and long-hydroperiod subtropical savannas $\left(1620 \mathrm{~km}^{2}\right.$ in area) are located interior to coastal regions, typically at elevations of $0.5-1 \mathrm{~m}$, 
and pine savannas and subtropical hardwood forests (60 $\mathrm{km}^{2}$ in area) occur on limestone outcroppings at elevations of 1-4 m. Fires have been recorded in all Everglades habitats; coastal marshes, seasonal savannas, and pine savannas are maintained by fire (W. B. Robertson, unpublished report). Most vegetation in these ecosystems resprouts or resists fire damage, but less fire-tolerant species, such as hardwoods, are strongly influenced by fire frequency and intensity.

\section{Annual cycles}

The Everglades are characterized by pronounced annual dry and wet seasons (Duever et al. 1994). The strongly seasonal hydrologic cycle defines the "water year," beginning with the dry season that typically extends from October to May (Fig. 1A). The wet season begins when rainfall increases in late May or early June, and the largest proportion of total annual rainfall occurs from June through September (Fig. 1A). Surface water levels are highest at wet season end in October and decline to their lowest levels by dry season end in May (Fig. 1B). Mean annual area burned each month peaks when surface water levels are lowest (Fig. 1C). About $80 \%$ of the total area that burns annually does so during the dry- to wet-season transition (AprilJune), and fires during May account for almost half the total annual area burned.

\section{ENSO indices}

We used two indices, Niño3 and Southern Oscillation Index (SOI), to characterize ENSO conditions. Niño3 is based on sea surface temperatures in the Pacific Ocean at latitude $5^{\circ} \mathrm{N}$ to $5^{\circ} \mathrm{S}$ and longitude $150^{\circ} \mathrm{W}$ to $90^{\circ} \mathrm{W}$. Monthly values of Niño3 anomalies from January 1950 through December 1999 were obtained from the NOAA Climate Prediction Center (USA). SOI is based on barometric pressure differences between Tahiti and Darwin, Australia (Troup 1965). Monthly values from January 1900 to December 1999 were obtained from the Queensland Centre for Climate Applications (Australia). Positive SOI and negative Niño3 correspond to cold surface waters across the eastern tropical Pacific and La Niña conditions; negative SOI and positive Niño3 correspond to warm waters and El Niño conditions.

\section{Data series}

Rainfall records for Florida Division 5, encompassing the Everglades region, were obtained from the National Climatic Data Center (USA) from the beginning of the record in January 1895 through December 1999. Everglades National Park provided records of daily surface water levels from October 1952 through December 1999 for well P33, located in Shark River Slough $\left(25^{\circ} 36^{\prime} 48.66^{\prime \prime} \mathrm{N}, 80^{\circ} 42^{\prime} 09.28^{\prime \prime} \mathrm{W}\right)$. We averaged the daily records for each month. Monthly counts of lightning strikes from the U.S. National Lightning Detection Network were purchased from Global Atmospherics
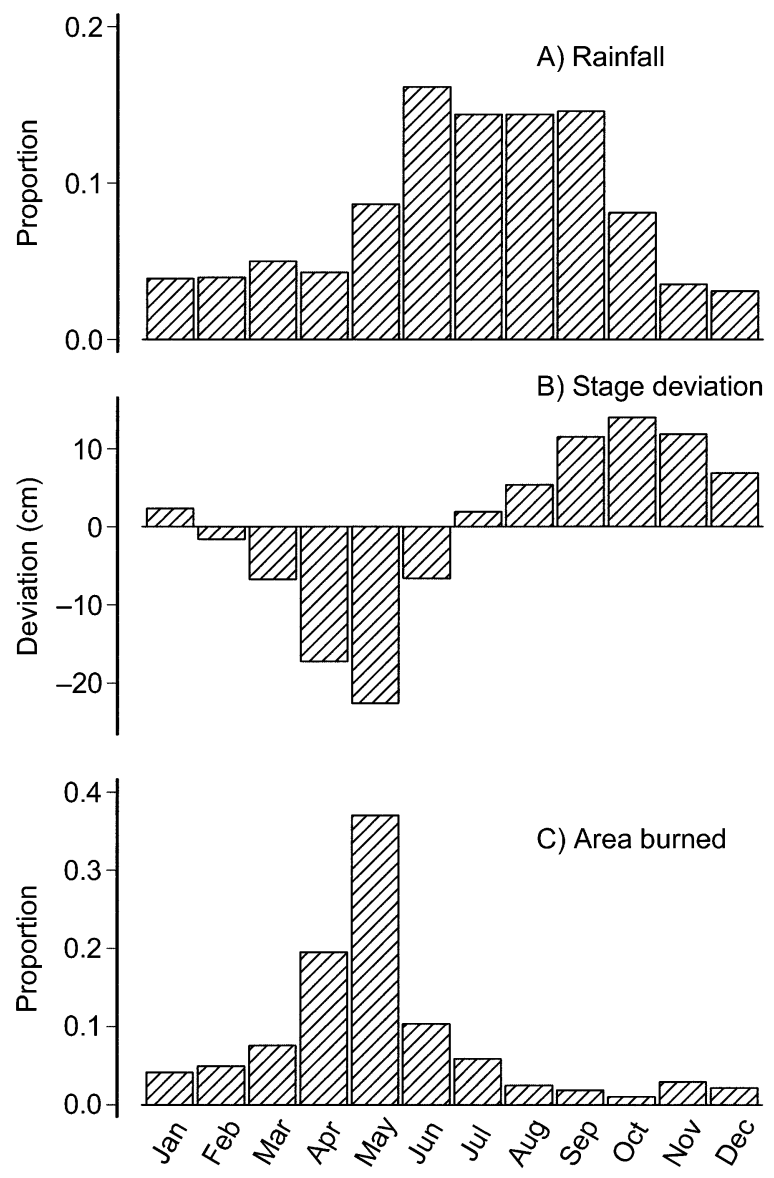

FIG. 1. The annual hydrologic cycle in the Florida Everglades and its relationship to area burned. (A) Proportion of annual rainfall occurring each month. (B) Monthly deviation from annual mean water level in well P33 in Shark Slough, Everglades National Park. Daily values of surface water level were partitioned into a seasonal component and trend using a moving average filter. The seasonal component is the deviation from the yearly average water level. Daily deviations were averaged across months within a year, and monthly deviations were then averaged across years. (C) The proportion of mean area burned each month. We used the period from January 1948 to December 1999 for panels A and C. Panel B used surface water level data from October 1952 to September 1980 because this was the longest period of record without missing values.

(Tucson, Arizona) for the period from January 1991 (the beginning of record) through December 1999 for the Everglades region $\left(25^{\circ} 15^{\prime}-25^{\circ} 45^{\prime} \mathrm{N}, 80^{\circ} 30^{\prime}-81^{\circ} 6^{\prime}\right.$ $\mathrm{W})$. Numbers of fires and area burned were compiled from Everglades National Park fire records from the beginning of the record in January 1948 through December 1999. We included records for the area within the original Park boundaries and for the East Everglades region later acquired by the Park. Data for each fire included date of ignition and termination, ignition source, and size of area burned. We assigned each fire to a month and year based on date of ignition and compiled monthly numbers of fires and area burned. 
TABLE 1. Spectral peaks corresponding to periodicities in area burned, number of fires, ENSO indices (Niño3, SOI), rainfall, and surface water levels in the Florida Everglades.

\begin{tabular}{cccccc}
\hline \hline \multicolumn{5}{c}{ Periodicity (yr) } \\
\hline Area burned & No. fires & Niño3 & SOI & $\begin{array}{c}\text { Division 5 } \\
\text { rainfall }\end{array}$ & $\begin{array}{c}\text { Surface } \\
\text { water } \\
\text { level }\end{array}$ \\
\hline $12.3(0.01)$ & & & $11.4(0.01)$ & $10.0(0.05)$ & $12.3(0.01)$ \\
& $5.7(0.01)$ & $5.0(0.01)$ & $6.1(0.01)$ & $5.7(0.01)$ & \\
$5.0(0.01)$ & & $3.4(0.01)$ & $3.6(0.01)$ & $3.3(0.10)$ & \\
$3.4(0.10)$ & & $2.7(0.01)$ & $2.8(0.05)$ & & $2.9(0.05)$ \\
& & & $2.4(0.01)$ & & \\
& $2.2(0.05)$ & $2.0(0.01)$ & $2.1(0.05)$ & $2.0(0.05)$ & \\
$1.0(0.01)$ & $1.0(0.01)$ & $1.4(0.01)$ & & $1.1(0.05)$ & $1.0(0.01)$ \\
\hline
\end{tabular}

Notes: The statistically significant peaks within time series are spaced to facilitate comparisons across time series. The period (in years) and $P$ value (in parentheses) are given for each spectral peak.

We included fires with lightning, incendiary (human caused, but not prescribed), or unknown ignition sources. We excluded prescribed fires as they reflect park policies rather than climatic variability.

\section{Data analysis}

We analyzed these data using both spectral analysis and linear correlation. The two analyses, described below, complement each other. We used spectral analysis to examine patterns within each time series (patterns can then be compared across time series) and correlation analysis to explicitly examine relationships between time series.

Spectral analysis identified dominant frequencies (spectral peaks) in each time series. We compared similarities across time series to infer relationships. We used the spectral analysis methods of Mann and Lees (1996) and software from the SSA-MTM Group, University of California, Los Angeles. The software implements a multiple-taper spectral analysis and assumes a red noise background. A red noise background was appropriate because of temporal persistence in climate systems (Mann and Lees 1996). The multipletaper method of spectral analysis is also robust to nonstationarity (Mann and Lees 1996). We report statistically significant periodicities and associated confidence levels. $P$ values were based on the assumption that the spectra are distributed as $\chi^{2}$ with $v$ degrees of freedom, where $v$ is approximately equal to twice the number of tapers used in the estimation of the spectrum. Therefore a $P$ value of 0.01 corresponds to a spectral estimate beyond the 99th quantile of the appropriate chi-square distribution. We limited our comparisons of spectra across time series to periodicities $\geq 1$ year because we were interested in variability across years. The spectra were calculated using the entire length of each time series to derive estimates as precisely as possible. Area burned was transformed $(\ln (x+1))$ prior to spectral analysis because of the skewness of the monthly time series. The lightning strike time series was relatively short (9 years) and thus excluded from spectral analysis.

We examined relationships between time series by computing their linear correlation $(\rho)$. Annual summaries were used as we were interested in variability in fire regimes across years. Monthly data were summarized with respect to water years to reflect the importance of the dry to wet-season transition (Fig. 1). ENSO indices and rainfall were summarized over October-April because rainfall during this period largely determines dry season severity and is sensitive to ENSO conditions (Duever et al. 1994). Surface water levels and lightning strike frequency were aggregated over March-June, the period of lowest surface water

TABLE 2. Linear correlations between fire regimes (annual area burned, annual number of fires), ENSO cycle (dry-season Niño3 and SOI), dry-season rainfall, and dry-season surface water level in the Florida Everglades.

\begin{tabular}{lcccc}
\hline \hline \multicolumn{1}{c}{ Variable } & Niño3 & SOI & $\begin{array}{c}\text { Divison 5 } \\
\text { rainfall }\end{array}$ & $\begin{array}{c}\text { Water } \\
\text { level }\end{array}$ \\
\hline Area burned & $-0.40(0.001)$ & $0.46(<0.001)$ & $-0.49(<0.001)$ & $-0.50(<0.001)$ \\
No. fires & $-0.35(0.039)$ & $0.23(0.099)$ & $-0.45(0.011)$ & $-0.46(0.002)$ \\
Surface water & $0.51(<0.001)$ & $-0.53(<0.001)$ & $0.72(<0.001)$ & \\
Division 5 rainfall & $0.65(<0.001)$ & $-0.62(<0.001)$ & & \\
SOI & $-0.87(<0.001)$ & & & \\
\hline
\end{tabular}

Notes: Details of yearly summaries are given in the Methods. The time series for number of fires was first detrended using a moving average filter, shortening the length of the time series. Correlations and $P$ values (bootstrapped, in parentheses) are based on the length of the shortest time series (41 years). 

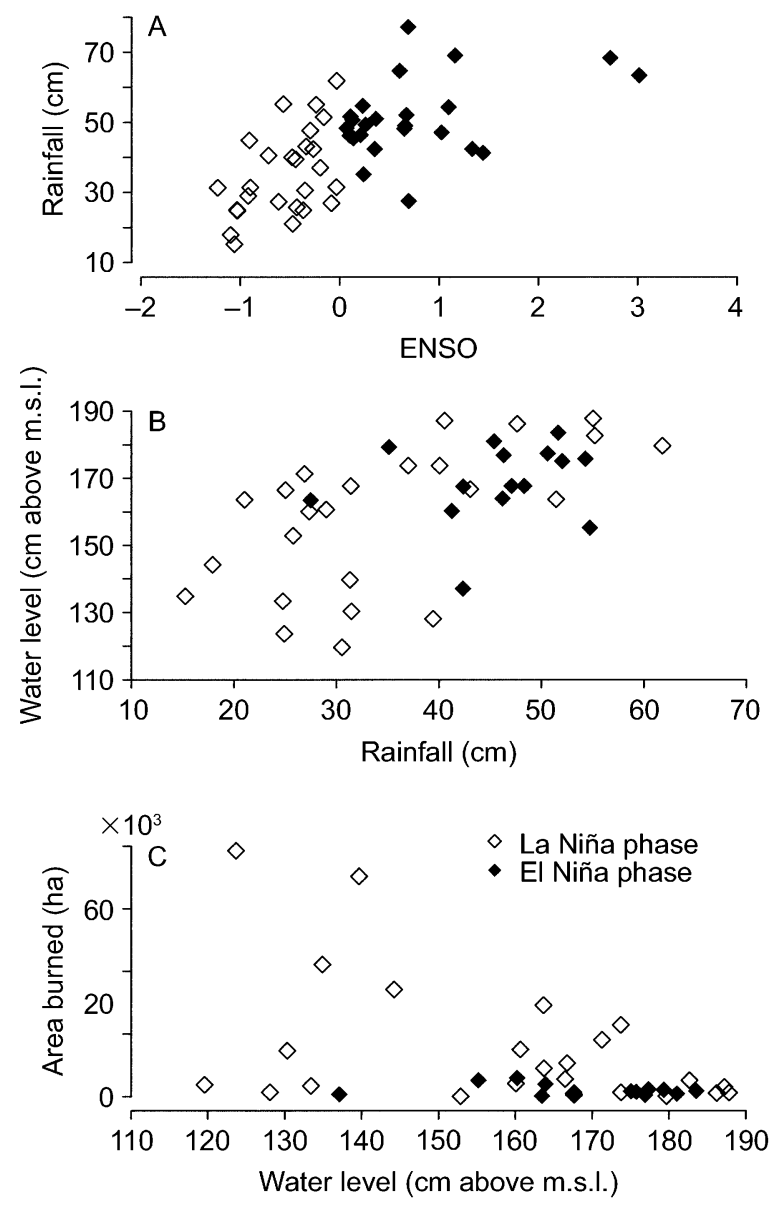

FIG. 2. The relationship between Everglades' area burned, rainfall, surface water level, and Niño3. (A) Total dry-season (October-April) rainfall and mean Niño3 ENSO (El Niño Southern Oscillation) index during the dry season (October-April). (B) Surface water level above mean sea level (m.s.l.) at dry-season end (mean, April-June) with respect to total dry-season (October-April) rainfall. (C) Annual area burned and surface water level at dry-season end (mean, April-June).

levels and largest areas burned. Area burned and numbers of fires were summed from October to September (i.e., water years). The statistical significance of linear correlations was established using a bootstrapping technique because the time series were autocorrelated (i.e., sequential observations were not independent). In the bootstrapping procedure, we created 2000 bootstrapped (surrogate) time series for one of the two time series (e.g., time series $\mathrm{ts}_{1}$ ). Each surrogate shared the same power spectrum and amplitude of the original time series (see Kaplan and Glass 1995). The linear correlation was calculated between the second time series $\left(\mathrm{ts}_{2}\right)$ and each of the 2000 bootstrapped $\mathrm{ts}_{1}$ 's (i.e., $\left.r_{1} \ldots r_{2000}\right)$, as well as with the observed time series $\left(r_{\text {obs }}\right)$. The statistical significance, i.e., two-tailed $P$ val$\mathrm{ue}$, of the relationship was computed by comparing $r_{\mathrm{obs}}$ to the distribution of $r_{1} \ldots, r_{2000}$.

\section{RESUlts}

Spectral analyses of monthly time series identified shared periodicities (spectral peaks) among area burned, Nino3, SOI, rainfall, and surface water level (Table 1). Area burned had four spectral peaks: 1.0, $3.4,5.0$, and 12.3 years. The 1.0- and 12.3-year cycles were similar to the 1- and 10-14 year cycles reported for south Florida by Gunderson and Snyder (1994). The 3.4- and 5.0-year spectral peaks matched periodicities in Niño3 precisely, and the 3.4-, 5.0-, and 12.3-year spectral peaks corresponded to periodicities in both SOI and rainfall. The 12.3-year cycle coincided precisely with a spectral peak in the surface water time series, suggesting a relationship between large areas burned and low surface water levels. The 1.0-year spectral peak reflects the influence of the annual hydrologic cycle on fire regime (Fig. 1).

There were three significant periodicities in number of monthly fires at 1.0, 2.2, and 5.7 years (Table 1). The spectral peak at 5.7 years coincided exactly with a periodicity in rainfall and was similar to a 6.1-year signal in SOI. The 2.2-year periodicity corresponded with signals of similar period in the Niño3, SOI, and rainfall time series. The absence of the 2.2-year cycle in the area burned time series suggests that this periodicity involves years with smaller fires. The spectral peak at 1.0 years again reflects the annual hydrologic cycle.

Annual variation in area burned and number of fires was related to ENSO conditions; area burned and number of fires were positively correlated with La Niña and

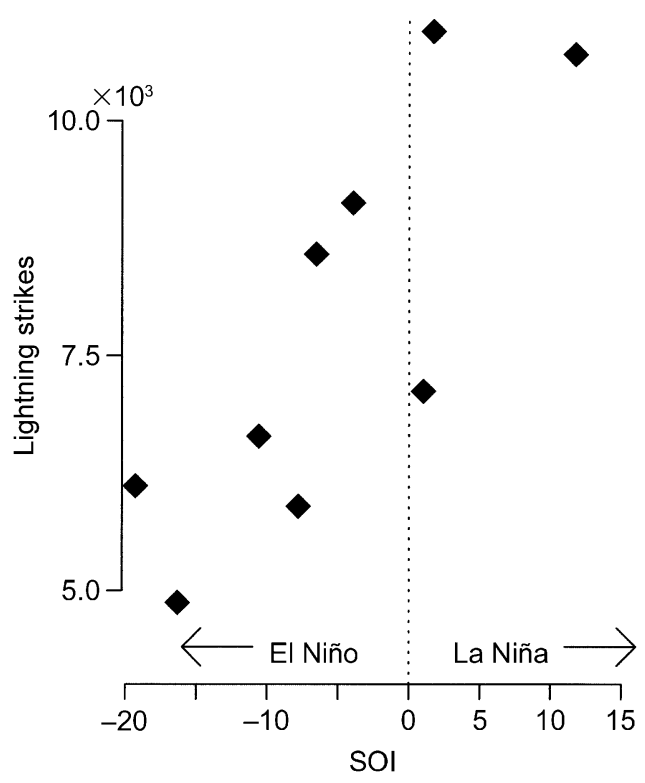

FIG. 3. The relationship between number of lightning strikes in the Everglades region of $25.25^{\circ} \mathrm{N}-25.75^{\circ} \mathrm{N}$ latitude and $80.5^{\circ} \mathrm{W}-81.1^{\circ} \mathrm{W}$ longitude during the dry-wet season transition (March-June) and dry-season ENSO (mean October-April SOI [Southern Oscillation Index]) from 1991 to 1999. 


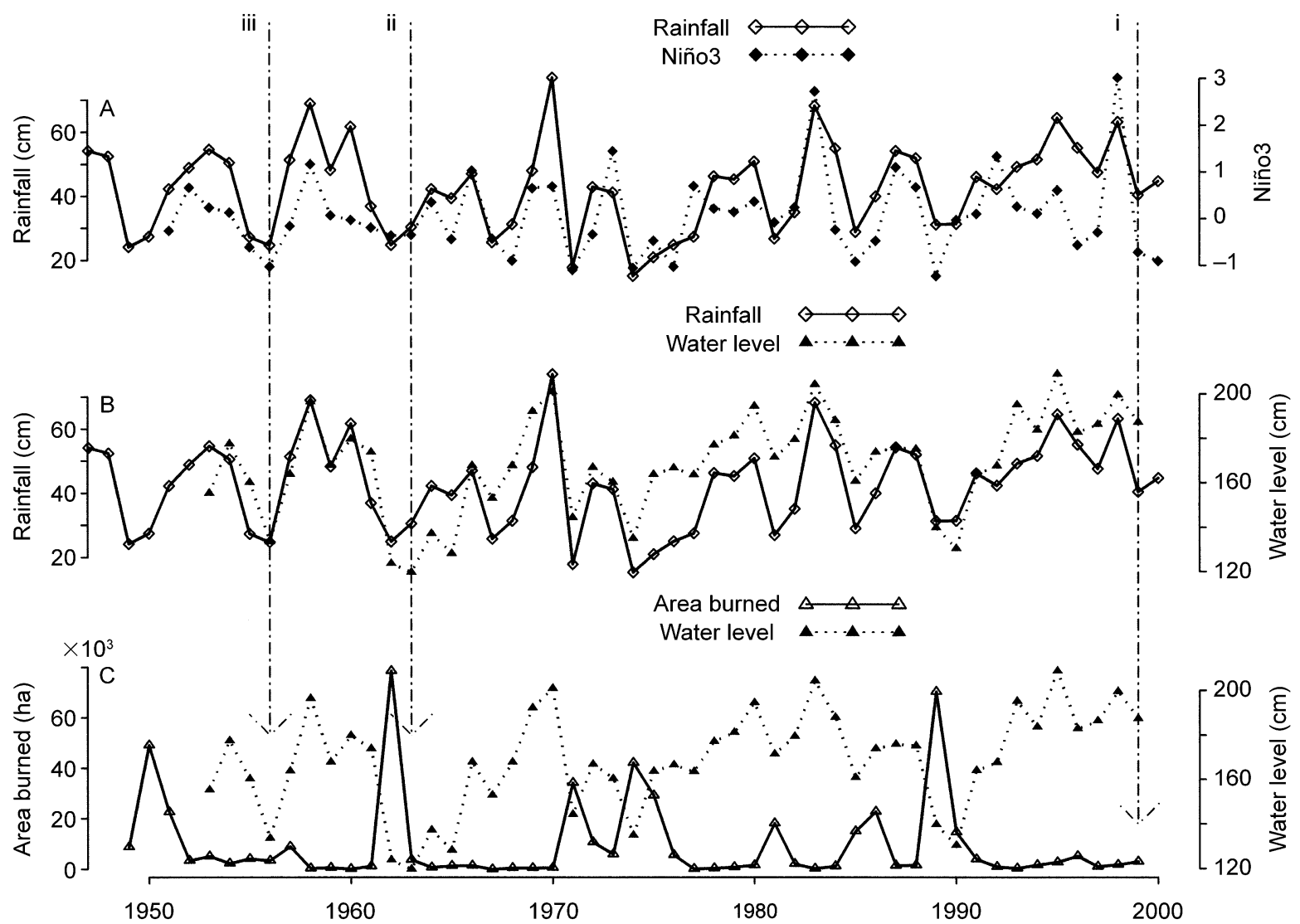

FIG. 4. Three departures (i, ii, and iii) from the expected relationship between ENSO and area burned that are examined in the Discussion. The figure presents time series of (A) total dry-season rainfall and mean Niño3 ENSO index, (B) surface water level at dry-season end and total dry-season rainfall, and (C) annual area burned and surface water level at dry-season end. Units and data are as in Fig. 2.

negatively correlated with El Niño conditions (Table 2). La Niña conditions, area burned, and numbers of fires were negatively correlated with surface water levels and rainfall (Table 2). The relationships between ENSO (Niño3), rainfall, surface water level, and area burned are shown in Fig. 2.

Lightning strike frequency during the transition from the dry to the wet season was related to the ENSO cycle. Both SOI $(\rho=0.81 ; P$ value $=0.027)$ and Niño3 $(\rho=-0.69 ; P$ value $=0.050)$ were correlated with lighting strike frequency (Fig. 3); increased lightning strikes occurred during La Niña phases and reduced strikes occurred during El Niño episodes.

\section{DISCUSSION}

During the past half-century, numbers and extent of fires in the Everglades increased during La Niña phases and decreased during El Niño phases of ENSO. Strong links between ENSO conditions and fires are likely to have occurred historically as ENSO events have occurred regularly for thousands of years (Tudhope et al. 2001). Such links should have produced predictable large-scale fires in the Everglades landscape (Beckage and Platt 2003), exerting a strong influence on ecolog- ical and evolutionary conditions over the 5000 years since the area emerged from the ocean (Douglas 1947). ENSO may similarly increase predictability of fire or drought in other ecosystems.

We propose that ENSO events have influenced Everglades fire regimes in two ways. First, ENSO conditions influence dry-season rainfall. El Niño phases increase dry-season rainfall, resulting in higher water levels in major drainages during the dry- to wet-season transition period. In contrast, La Niña phases produce decreased dry-season rainfall, and major drainages often contain no water during the transition period. This increases spatial continuity of pyrogenic, graminoiddominated fine fuels (Slocum et al. 2003), so that fires are likely to spread over large areas during La Niña phases, rather than several years after El Niño phases as in some other ecosystems (e.g., Baisan and Swetnam 1990, Veblen and Kitzberger 2002). Second, the ENSO cycle influences the frequency of lightning strikes and, thus, the probability of ignition during the dry to wet season transition. El Niño phases that produce more clouds, increased rainfall, and high surface water levels during the transition may slow warming of the land surface. This might result in fewer convective thun- 

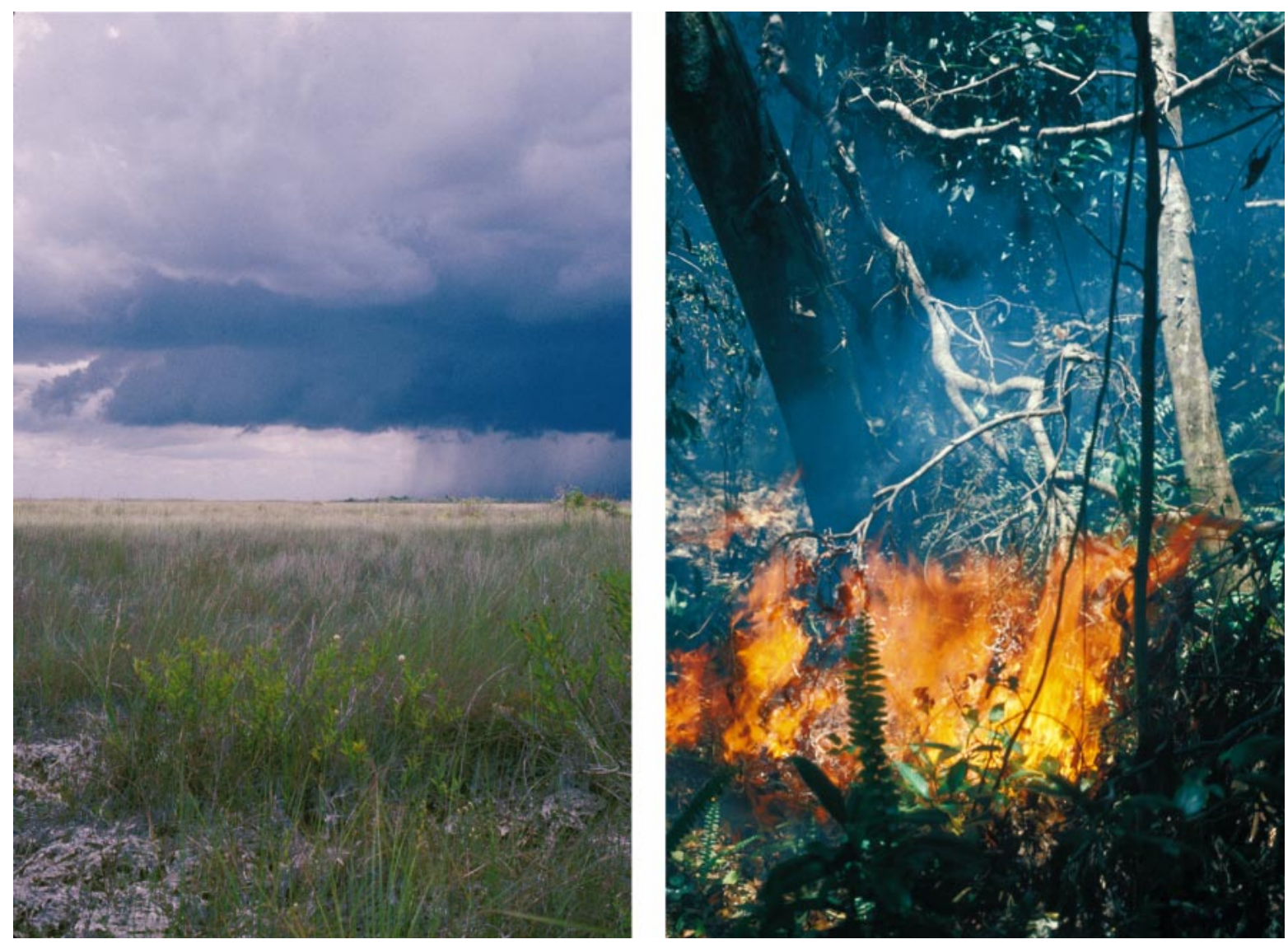

Plate 1. (Left) A thunderstorm over Taylor Slough in Everglades National Park. Lighting strikes from such storms provide a natural source of ignition for wildfires. (Right) The Ingraham Fire burning a tropical hardwood hammock. Fires are most likely to naturally enter hardwood hammocks in the dry-season to wet-season transition during severe droughts associated with La Niña conditions. The burning of litter and humus in hardwood hammocks during these extreme events begins the transformation of the hammock into an open pineland.

derstorms and fewer lightning strikes, contributing to reduced numbers of fires. In contrast, fewer clouds, decreased rainfall, and low surface water levels during La Niña phases could cause rapid surface warming, resulting in more thunderstorms and lightning strikes and increased likelihood of ignition of dry fuels over large areas, contributing to larger numbers of fires. We emphasize that increased numbers of lightning strikes coincide with La Niña drought conditions, leading to potentially extensive fires. The 1989 Ingraham Fire, an example of such a La Niña-influenced fire, was ignited by five separate lightning strikes and burned 40000 ha over 1.5 months (see Plate 1). Similar large, lightning initiated fires probably occurred historically during major La Niña phases when water levels were low throughout the Everglades and may be responsible for the prevalence of fire-adapted communities in the Everglades (W. B. Robertson, unpublished report).

Deviations from the expected relationship between ENSO and Everglades fire regimes during the past 50 years have involved three conditions. First, increased rainfall near the end of the wet season from tropical storms may result in high surface water levels during the dry-wet season transition even during La Niña phases. For example, Hurricane Georges and tropical storm Mitch both influenced southern Florida weather in September and November 1998 respectively, producing increased rainfall and high water levels and reducing area burned in 1999 despite La Niña conditions (Fig. 4i). Second, years of few and small fires during La Niña conditions and low surface water levels have followed years when large areas burned. These deviations likely reflect the 2-3 years required for postfire recovery of fine fuels (Gunderson and Snyder 1994). For example, the 1962 peak in area burned (the largest single fire in park history) was followed by several years with small annual areas burned, despite low surface water levels in 1963 and 1965 (Fig. 4ii). Third, large fires during La Niña episodes may have been prevented because of anthropogenic firebreaks or suppression. For example, large fires occurred in the northern Everglades during a severe La Niña drought in 1955-1956 (Loveless 1959) but would have had to cross US 41 to enter Everglades National Park. Only 
a small area subsequently burned inside the Park during this period despite severe La Niña conditions (Fig. 4iii).

Global warming may indirectly influence ecosystems in the Everglades through the ENSO-fire relationship. The composition and structure of ecosystems in the Everglades are sensitive to fire frequency (Robertson 1953). ENSO events are expected to increase in severity and frequency with global warming (Timmermann et al. 1999), possibly creating conditions favoring less frequent but more severe, large-scale fires. Relationships between ENSO and fire regimes may constitute an indirect path whereby global warming influences ecosystems other than through shifts in species' ranges along temperature gradients (Overpeck et al. 1991, Holmgren et al. 2001).

\section{ACKNOWLEDGMENTS}

We thank Daniel Kaplan for a time series bootstrapping function and Louis Gross, Kerry Woods, and two anonymous reviewers for comments that greatly improved the manuscript. Brian Beckage gratefully acknowledges financial support from the University of Tennessee, the National Science Foundation, and the National Parks Ecological Research Fellowship Program, a program funded by the National Park Foundation through a generous grant from the Andrew W. Mellon Foundation.

\section{Literature Cited}

Allan, R. J., J. Lindesay, and D. E. Parker. 1996. El Niño Southern Oscillation and climatic variability. CSIRO Publishing, Collingwood, Victoria, Australia.

Baisan, C. H., and T. W. Swetnam. 1990. Fire history on a desert mountain range: Rincon Mountain Wilderness, Arizona, U.S.A. Canadian Journal of Forest Research 20: 1559-1569.

Beckage, B., and W. J. Platt. 2003. Predicting severe wildfire years in the Florida Everglades. Frontiers in Ecology and the Environment 1:235-239.

Beckage, B., and I. J. Stout. 2000. The effects of repeated burning on species richness in Florida sandhills: a test of the intermediate disturbance hypothesis. Journal of Vegetation Science 11:113-122.

Bond, W. J., and J. J. Midgley. 2001. Ecology of resprouting in woody plants: the persistence niche. Trends in Ecology and Evolution 16:45-51.

Bond, W. J., and B. W. van Wilgen. 1996. Fire and plants. Chapman and Hall, New York, New York, USA.

Brenner, J. 1991. Southern Oscillation anomalies and their relation to Florida wildfires. International Journal of Wildland Fire 1:73-78.

Douglas, M. S. 1947. The Everglades: river of grass. Hurricane House, Miami, Florida, USA.

Duever, M. J., J. F. Meeder, L. C. Meeder, and J. M. McCollum. 1994. The climate of south Florida and its role in shaping the Everglades ecosystem. Pages 225-248 in S. M. Davis and J. C. Ogden, editors. Everglades: the ecosystem and its restoration. St. Lucie Press, Delray Beach, Florida, USA.

Glitzenstein, J. S., W. J. Platt, and D. R. Streng. 1995. Effects of fire regime and habitat on tree dynamics in north Florida longleaf pine savannas. Ecological Monographs 65:441476.

Gunderson, L. H., and J. R. Snyder. 1994. Fire patterns in the southern Everglades. Pages 291-305 in S. M. Davis and J. C. Ogden, editors. Everglades: the ecosystem and its restoration. St. Lucie Press, Delray Beach, Florida, USA.

Higgins, S. I., W. J. Bond, and W. S. W. Trollope. 2000. Fire, resprouting, and variability: a recipe for grass-tree coexistence in savanna. Journal of Ecology 88:213-229.

Holmgren, M., M. Scheffer, E. Ezcurra, J. R. Gutierrez, and G. M. J. Mohren. 2001. El Niño effects on the dynamics of terrestrial ecosystems. Trends in Ecology and Evolution 16:89-94.

Johnson, E. A. 1992. Fire and vegetation dynamics: studies from the North American boreal forest. Cambridge University Press, Cambridge, UK.

Kaplan, D., and L. Glass. 1995. Understanding nonlinear dynamics. Springer, New York, New York, USA.

Loveless, C. M. 1959. A study of the vegetation in the Florida Everglades. Ecology 40:1-9.

Mann, M. E., and J. M. Lees. 1996. Robust estimation of background noise and signal detection in climatic time series. Climatic Change 33:409-445.

Mutch, R. W. 1970. Wildland fires and ecosystems-a hypothesis. Ecology 51:1046-1051.

Overpeck, J. T., P. J. Bartlein, and T. Webb, III. 1991. Potential magnitude of future vegetation change in eastern North America: comparisons with the past. Science 254: 692-695.

Platt, W. J. 1999. Southeastern pine savannas. Pages 23-51 in R. C. Anderson, J. S. Fralish, and J. Baskin, editors. The savanna, barren, and rock outcrop communities of North America. Cambridge University Press, Cambridge, UK.

Slocum, M. G., W. J. Platt, and H. C. Cooley. 2003. Effects of differences in prescribed fire regimes on patchiness and intensity of fires in subtropical savannas of Everglades National Park, Florida. Restoration Ecology 11:91-102.

Swetnam, T. W., and J. L. Betancourt. 1990. Fire-southern oscillation relations in the southwestern United States. Science 249:1017-1020.

Timmermann, A., J. Oberhuber, A. Bacher, M. Esch, M. Latif, and E. Roeckner. 1999. Increased El Niño frequency in a climate model forced by future greenhouse warming. Nature 398:694-697.

Troup, A. J. 1965. The Southern Oscillation. Quarterly Journal of the Royal Meteorological Society 91:490-506.

Tudhope, A. W., C. P. Chilcott, M. T. McCulloch, E. R. Cook, J. Chappell, R. M. Ellam, D. W. Lea, J. M. Lough, and G. B. Shimmield. 2001. Variability in the El Niño-Southern Osillation through a glacial-interglacial cycle. Science 291: 1511-1517.

Veblen, T. T., and T. Kitzberger. 2002. Inter-hemispheric comparison of fire history: the Colorado Front Range, U.S.A. and the Northern Patagonian Andes, Argentina. Plant Ecology 163:187-207. 